\title{
Thinking outside the 'health' box: interventions for malaria control
}

\author{
Steve Lindsay \\ From Challenges in malaria research \\ Basel, Switzerland. 10-12 October 2012
}

In the last decade malaria has declined sharply in many countries in the tropics, due largely to the massive expansion of control programmes. However, the future may not be as bright as drug and insecticide resistance rises and aid budgets constrict. Since it is well recognised that malaria declined in many parts of the world due to socioeconomic improvements, here I consider whether development today could be an effective weapon against malaria.

Published: 15 October 2012

Submit your next manuscript to BioMed Central and take full advantage of:

- Convenient online submission

- Thorough peer review

- No space constraints or color figure charges

- Immediate publication on acceptance

- Inclusion in PubMed, CAS, Scopus and Google Scholar

- Research which is freely available for redistribution 